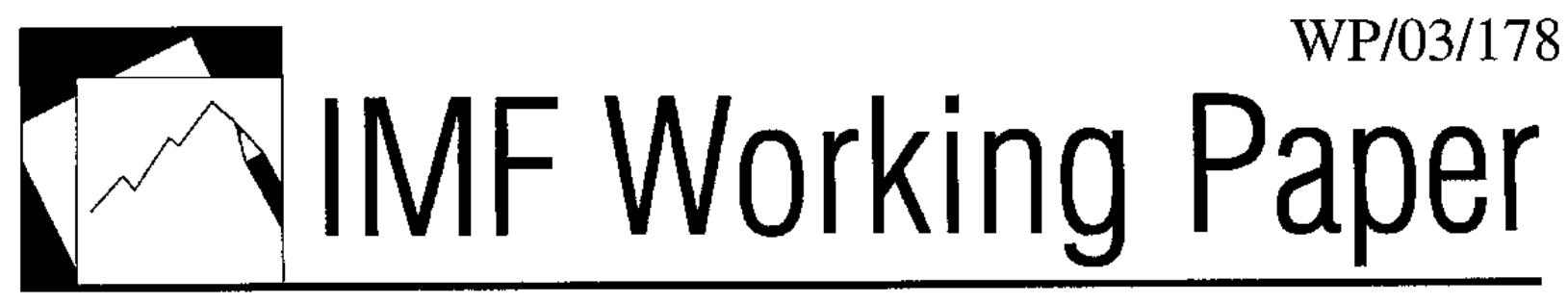

\title{
Potential Output and Total Factor Productivity Growth in Post-Apartheid South Africa
}

Vivek Arora and Ashok Bhundia 


\title{
IMF Working Paper
}

\section{African Department \\ Potential Output and Total Factor Productivity Growth in Post-Apartheid South Africa}

\author{
Prepared by Vivek Arora and Ashok Bhundia ${ }^{1}$ \\ Authorized for distribution by Doris C. Ross
}

September 2003

\begin{abstract}
The views expressed in this Working Paper are those of the author(s) and do not necessarily represent those of the IMF or IMF policy. Working Papers describe research in progress by the author(s) and are published to elicit comments and to further debate.
\end{abstract}

This paper provides estimates of potential output growth in post-apartheid South Africa using both time trend techniques and a production function approach which indicates a potential growth rate of around 3 percent. The implied output gap provides statistically significant information for predicting inflation and could thus provide valuable input for formulating macroeconomic policy. Growth accounting and regression analysis suggest that an increase in trend GDP growth after the end of apartheid in 1994 is attributable to higher TFP growth driven by trade liberalization and greater private sector participation.

JEL Classification Numbers: O40, O47, O55

Keywords: Potential output, output gap, total factor productivity, South Africa

Authors’ E-Mail Addresses: varora@imf.org, abhundia@imf.org

${ }^{1}$ The authors are grateful to Michael Nowak, Doris Ross, Paul Cashin, Luca Ricci, Matthias Vocke, and Qing Wang for helpful comments on this paper, and to Gustavo Bagattini for excellent research assistance. 


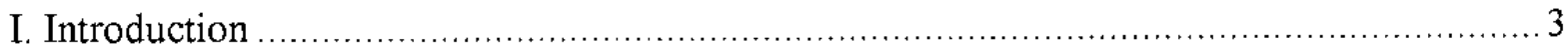

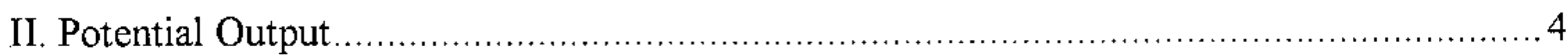

A. Estimating Potential Output: Alternative Methods..................................... 4

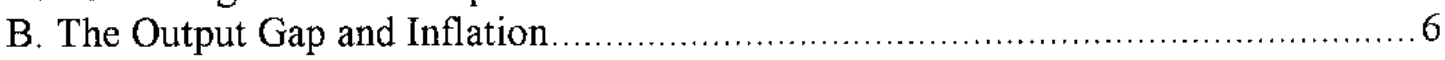

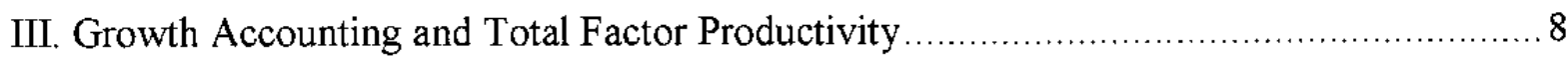

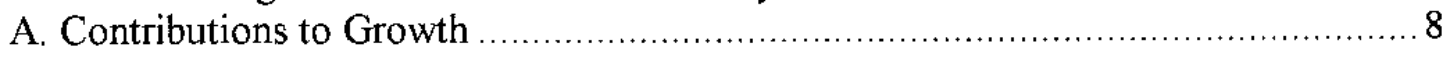

B. Determinants of Total Factor Productivity:

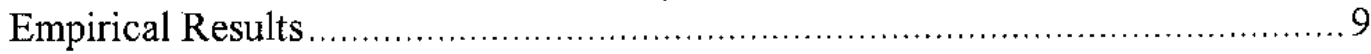

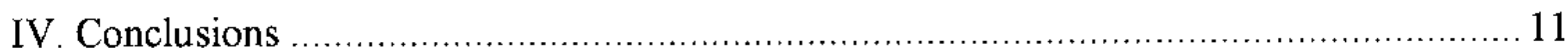

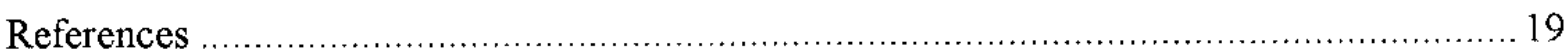

Tables

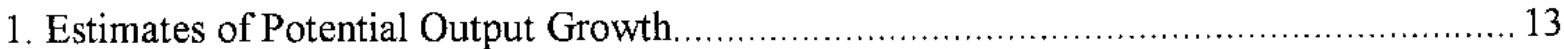

2. Output gap in 2001 and Collerelations with Capacity Utilization ........................... 13

3. Phillips Curve Estimates Using the Output Gap Measures ...................................... 13

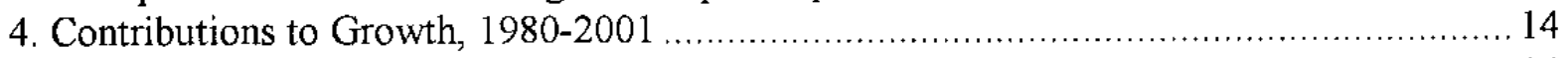

5. Selected Factors Affecting TFP Growth, 1980-2001 ..................................... 14

6. The Johansen Cointegrating Test for TFP, OPEN and P1 ................................. 17

7. The Error-Correction Process and Test of Weak Exogeneity …............................. 17

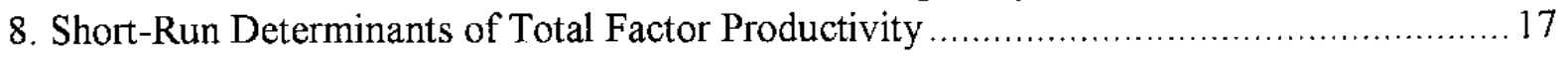

Figures

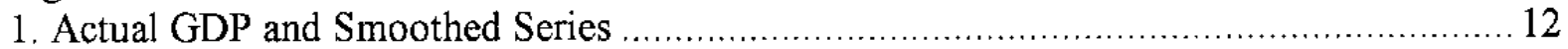

2. Actual Output, Potential Output, and Output Gap, 1980-2001 ............................... 15

3. Output Gap, Inflation, and Capacity Utilization, 1980-2001 ............................... 16 


\section{INTRODUCTION}

Estimates of potential output have a variety of uses in macroeconomic policy formulation. The output gap (measured as the difference between actual and potential output) can be an important input for monetary policy decisions as it provides an indication of the intensity of resource utilization and of inflationary pressures, including in the context of various Phillipscurve models. The gap can also be used for gauging the stance of fiscal policy in a cyclical context through its role in calculating structural measures of the fiscal balance.

This paper provides an assessment of potential output and the sources of growth in postapartheid South Africa, on which relatively little empirical work exists. ${ }^{2}$ It should be pointed out that the paper focuses on potential output in the conventional sense, which is based on historical rates of factor (labor and capital) utilization and total factor productivity. It does not focus on potential output in the more colloquial sense of how much output the economy could produce if hitherto unemployed resources were all to be employed. The latter kind of calculation is more useful for assessing long-run growth prospects and is discussed in the South African context by Arora, Bhundia, and Bagattini (2003), De Wet (1995), and Strydom (1995). Here the focus is on potential output as conventionally used for macroeconomic policy analysis.

The paper provides estimates of potential real GDP growth in South Africa based on alternative methodologies, including a production function approach that is standard in the literature. ${ }^{3}$ The estimates suggest that during 1994-2001, potential output growth was around $2^{1 / 4}-3$ percent annually and that the output gap in 2001 was roughly zero. Phillips curve regressions indicate that the output gaps implied by each of the three methods for estimating potential output provide significant information about inflationary pressures in South Africa.

In addition, the paper sheds light on a striking feature of South Africa's growth experience in recent years: the significant increase in the growth rate of real GDP during the post-apartheid period, from an average of 1 percent in 1980-93 to 2.8 percent in 1994-2001. ${ }^{4}$ A growth-

${ }^{2}$ A notable exception, albeit not recent, is De Jager and Smal (1984).

${ }^{3}$ See U.S. Congressional Budget Office (2001) and DeMasi, Chan Lau, and Keenan (1999) for a description of the production-function approach and estimates based on alternative methodologies for the United States, respectively. See Dupasquier, Guay, and St-Amant (1997) for a general discussion of alternative methodologies.

${ }^{4}$ A likelihood ratio test for a structural break in the real GDP series indicated a break in 1993. The recent data also reflect a statistical revision in June 1999, which implemented the 1993 System of National Accounts and resulted in an upward revision in measured annual real GDP growth during $1994-98$ from 2.2 percent to 2.7 percent. 
accounting exercise suggests that the increase can be attributed principally to higher totalfactor-productivity (TFP) growth-or improvements in efficiency and technology-rather than to increases in the factors of production. The paper provides evidence that private investment in machinery and equipment and trade liberalization have contributed to the upturn in TFP growth.

\section{Potential OutPut}

Measures of potential output are intended to capture the level of output that an economy can produce based on the available factors of production (labor and capital) and the efficiency with which they are combined (total factor productivity). The measures are typically based on historical rates of factor utilization and total factor productivity, rather than on literal "full" employment, so that over time the average output gap is roughly zero.

\section{A. Estimating Potential Output: Alternative Methods}

Since estimates of potential output are subject to considerable uncertainty, it is important to use several alternative estimation techniques rather than to rely on any one technique in particular. In this paper, we implement three commonly used techniques for estimating potential output: a univariate HP filter; a bivariate structural VAR that uses information on inflation developments to distinguish between permanent and transitory movements in output; and a neoclassical Cobb-Douglas production function with constant returns to scale.

\section{Hodrick-Prescott (HP) Filter}

A common technique used for detrending economic time series is the Hodrick-Prescott (HP) filter. ${ }^{5}$ In the context of the real GDP series, the HP filter derives a "trend" output such that it minimizes a weighted average of the gap between actual output, $Y_{t}$, and trend output, $Y^{*}$, and the rate of change in trend output, or its smoothness, over the whole sample period:

$$
\min \frac{1}{T} \sum_{t=1}^{T}\left(\ln Y_{t}-\ln Y_{t}^{*}\right)^{2}+\frac{\lambda}{T} \sum_{t=2}^{T-1}\left[\left(\ln Y_{t+1}^{*}-\ln Y_{t}^{*}\right)-\left(\ln Y_{t}^{*}-\ln Y_{t-1}^{*}\right)\right]^{2}
$$

where $\mathrm{T}$ is the number of observations, and $\lambda$ is the factor that determines the smoothness of the trend. ${ }^{6}$ A major disadvantage of the HP filter is that, since it is a two-sided symmetric filter, the estimated trend output series suffers from end-point biases. The method also fails to take account of structural breaks in the output series, instead smoothing out such changes.

\section{Structural Vector Autoregressions}

In the structural vector autoregression (SVAR) approach, potential output is driven by permanent supply shocks, while transitory fluctuations are driven by demand shocks

\footnotetext{
${ }^{5}$ See Hodrick and Prescott (1997).

${ }^{6}$ Studies of the U.S. economy that rely on quarterly data use $\lambda=1600$.
} 
(Blanchard and Quah, 1989). Whereas Blanchard and Quah (1989) use output and unemployment in their VAR, the present analysis uses output and inflation because of the lack of reliable employment data in South Africa. The role of inflation is to indicate whether output shocks are permanent or temporary. Permanent (supply) shocks are assumed to have a long-run impact on output but not on prices, while temporary (demand) shocks are assumed to have a long-run impact only on prices. ${ }^{7}$ The estimated VAR is thus structural in the sense that supply and demand shocks are identified by imposing restrictions on the long-run impact of these shocks on output and inflation. ${ }^{8}$

A bivariate VAR was estimated consisting of quarterly real GDP growth and inflation rates. ${ }^{9}$ Consistent with the Schwartz criterion test for the optimal lag length, four lags were included in the VAR to ensure there was no serial correlation in the residuals while allowing for any lags in the response of inflation to fluctuations in output growth. From the reduced form residuals the structural shocks were identified using the restrictions on the long-run impact of these shocks, as mentioned above. The impulse response functions confirmed, consistent with economic theory, that, in the short run, inflation and output both increase in response to a positive demand shock, and that output increases and inflation declines in response to positive supply shocks. ${ }^{10}$

\section{Production Function Approach}

A drawback of potential output estimates based on statistical time trend techniques is that they do not have an economic basis, in the sense that they are not based on the available factors of production. In contrast, a production function approach explicitly models output in terms of the factors of production and TFP, following a fairly well-known procedure. ${ }^{11}$ First, a functional form is assumed for the aggregate production function, with a standard

${ }^{7}$ See Blanchard and Quah (1989) for a detailed formulation of the restrictions.

${ }^{8}$ An advantage of this structural VAR approach is that it draws on clear theoretical foundations regarding the long-run impact of supply and demand shocks, while leaving the short-run impact unconstrained. However, a potential weakness of the method is that its reliability depends on the extent to which inflation is a good indicator of cyclical output developments. Another constraint is that the number of structural shocks that can be identified is limited by the number of variables being used in the analysis.

${ }^{9}$ Growth rates were used rather than levels because the levels of real GDP and the consumer price index (CPIX) were found to be non-stationary according to augmented Dickey-Fuller tests. The Johansen and Juselius test for cointegration failed to reject the null hypothesis of no cointegration, indicating that it was not necessary to include error-correction terms in the VAR.

${ }^{10}$ The impulse response function graphs are available on request.

${ }^{11}$ See U.S. Congressional Budget Office (2001) and DeMasi, Chan Lau, and Keenan (1999) for a description of the methodology and an application to the United States. 
assumption being a Cobb-Douglas function with constant shares over time for labor and capital. ${ }^{12}$ Next, TFP growth is derived as the difference between observed real GDP growth and the weighted sum of employment and capital growth ${ }^{13}$ The potential growth rates of TFP and employment are derived by assuming that TFP and employment were at their potential levels during two periods that are judged to have been cyclical peaks, and that their potential growth rates are equal to the trend (HP) growth rates between those peak years. ${ }^{14}$ Finally, potential GDP growth is estimated as potential TFP growth plus the weighted sum of the growth in potential employment and the capital stock. ${ }^{15}$

\section{Results}

The two statistical detrending techniques and the production function approach all indicate a pickup in the average annual potential output growth rate to $2 \frac{1 / 4-3}{4}$ percent during 1994-2001, from 1-11/4 percent during 1980-93 (Table 1). The pickup mirrors the increase in the average actual rate of growth, from 1 percent to $2 \frac{3 / 4}{4}$ percent, over the period. ${ }^{16}$

\section{B. The Output Gap and Inflation}

The output gap is measured as the difference between the level of actual and potential output. ${ }^{17}$ The level of potential output can be determined by applying the estimated growth rate of potential to the level of actual output in a base year in which output is judged to have

${ }^{12}$ In this paper, for South Africa the shares of labor and capital in output are assumed to be equal to their shares in national income-55 percent and 45 percent, respectively. The use of national-income shares has been criticized by Sarel (1997), as discussed below, but the results do not vary significantly with alternative assumptions regarding the labor and capital shares.

${ }^{13}$ The weights are the respective shares of labor and capital in total income (GDP), which under the assumption of competitive factor pricing are equal to the exponents of labor and capital in the production function. Employment is used as the labor variable because it is employment, rather than the total labor force, that has contributed to past production.

${ }^{14}$ These are assumed to be 1981 and 1996, on the basis of output gaps estimated from HP filters and of other indicators of resource utilization, and are consistent with the South African Reserve Bank's characterization of past business cycles in South Africa (SARB, 2003).

${ }^{15}$ The capital stock is used in its actual rather than its smoothed form because it is assumed to be fully utilized. Also, it is lagged one period. These are standard assumptions (e.g., see U.S. CBO (2001)).

${ }^{16}$ The disparity between the HP results and the other results, and between the HP results and actual growth, may be due to the end-point problem to which HP estimates are susceptible.

${ }^{17}$ The output gap is usually expressed as a percent of potential output. 
been close to potential based on other indicators of resource utilization. Real GDP appears to have been close to its potential level in 1998, as evidenced by a trough in inflation and a capacity utilization rate that was very close to its long-run average.

A key use of the output gap in policy analysis derives from its potential usefulness as an indicator of the intensity of resource utilization and the buildup of inflationary pressures. Simple correlations indicate a positive relationship of the estimated output gap with changes in CPI inflation, with a lag of one year, and with deviations in manufacturing capacity utilization around a long-run average (Table 2 and Figure 3). ${ }^{18}$ A formal test for a statistically significant relationship between the change in inflation and measures of the output gap can be conducted as follows (based on Coe and McDermott, 1997):

Model 1

$$
\Delta \pi_{t}=\alpha_{1}+\sum_{i=0}^{p} \beta_{1 i} G A P_{t-i}+\varepsilon_{1 t}
$$

where $\Delta \pi_{t}$ is the first difference of the inflation rate, and GAP is the output gap as a percent of potential output. ${ }^{19}$ The output gap enters the equation in both contemporaneous and lagged forms, with the lag length being determined by a minimization of the Schwartz (1978) criterion. An F-test is used to test for the joint significance of the $\beta_{1 i}$ coefficients. ${ }^{20}$

A special case of model 1 (model 2 below) can be estimated which relates the change in inflation, $\Delta \pi_{\mathrm{t}}$, to the change in the output gap, $\Delta \mathrm{GAP}_{\mathrm{t}}$, implying the constraint that successive lags of the level of the output gap alternate in sign, with each pair equal in absolute value (that is, $\beta_{11}=-\beta_{10}$, and so on).

Model 2

$$
\Delta \pi_{t}=\alpha_{2}+\sum_{i=0}^{\rho} \beta_{2 i} \Delta G A P_{t-i}+\varepsilon_{1 t}
$$

The estimation results for models 1 and 2 suggest that the output gap measures provide significant information about inflation in South Africa (Table 3). In model 2, changes in the output gap across all three measures provide statistically significant information about inflation, although in model 1 only the SVAR-based level of the output gap is statistically

${ }^{18}$ The estimates are based on the output gap derived from the production function approach, which is used because it has the strongest economic basis. However, as noted, the results are not significantly different from those based on the other approaches. The correlation coefficients are 0.22 and 0.87 , respectively, using the output gap from the production function approach.

${ }^{19}$ Following Coe and McDermott (1997), model 1 is derived from an inflation-expectationsaugmented Phillips curve with adaptive expectations.

${ }^{20}$ The inflation and output gap variables are both trend stationary according to ADF tests. 
significant. ${ }^{21}$ Diagnostic tests indicate the residuals are white noise for each of the models, indicating the absence of any significant mis-specification errors. Residual serial correlation was rejected at the 5 percent level based on a Breusch-Godfrey test. Tests for ARCH errors were also not significant at the 5 percent level.

\section{Growth Accounting and Total Factor Productivity}

\section{A. Contributions to Growth}

A growth accounting exercise based on the Cobb Douglas production function suggests that the significant increase in real GDP growth after 1994 reflects a substantial increase in TFP growth rather than greater factor accumulation (Table 4) ${ }^{22}$ The significance of the prominent role of TFP in South Africa's recent growth performance is that GDP growth can generally be sustained over longer periods of time when it is based on improvements in technology and efficiency - which are embodied in TFP_rather than on factor accumulation, which is subject to inherent limits based on demographics and diminishing returns.

The decline in the contributions to growth of capital and labor during 1994-2001 relative to the previous period reflects a continuation of the slowing in factor accumulation that started in the 1980s. Average annual growth in the capital stock declined from just over 2 percent during 1980-93 to 1.3 percent during 1994-2001. Employment actually shrank during 19942001 , as the positive annual average growth of 0.2 percent during 1980-93 was replaced by negative growth of 1.6 percent. ${ }^{23}$ As a result, the contribution to GDP growth of capital and labor together fell from 1 percentage point annually during 1980-93 to negative 0.3 percentage points during 1994-2001.

The decline in the contribution from factor accumulation was more than offset by a substantial increase in TFP growth. ${ }^{24}$ The turnaround in TFP performance in the recent

${ }^{21}$ Changes in the terms of trade were also included in the regressions to account for South Africa's openness to foreign trade and therefore foreign inflation shocks. However, the results reported in Table 3 were not found to be sensitive to this modification.

${ }^{22}$ This reinforces the conclusion of a previous staff study on the subject of growth accounting, which found that TFP growth turned around during the early 1990 s and bolstered a flagging growth performance (see IMF, 1998). The data for the subsequent period indicate that the increase in TFP growth has been sustained and has contributed to a substantial increase in real GDP growth.

${ }^{23}$ See Lewis (2001) for a discussion of some of the factors behind the employment decline.

${ }^{24}$ This general conclusion is robust to alternative assumptions regarding the shares of capital and labor in output. The use of national-income-based shares is sometimes criticized in part because it assumes that capital and labor markets are perfectly competitive. In South Africa, with large imperfections in labor market, the assumption may be unrealistic. However, an alternative estimate of the labor share based on Sarel (1997), which uses a disaggregated approach and adjusts for market imperfections, is 0.68 instead of 0.55 . Under this alternative 
period reflects in part the policy and institutional changes during the period (see IMF, 1998). International trade and investment offer important vehicles for technological spillover effects and greater private sector participation in the economy increases the scope for technological innovation. In South Africa, the scope for such effects has increased with the increasing openness of the economy; a rising share of capital goods in imports; and a greater share of investment, including in equipment and machinery, being accounted for by the private sector.

\section{B. Determinants of Total Factor Productivity: Empirical Results}

Theory and evidence suggest that several factors can contribute to TFP growth. Economic policies and institutions play a key role in increasing TFP, as highlighted in the endogenous growth literature. Research and development (R\&D) can be an important determinant of TFP growth (Romer, 1997; Grossman and Helpman, 1997), although it does not appear to have played a major part in the case of South Africa. ${ }^{25}$ Foreign direct investment can contribute to TFP through technological spillovers (Coe, Helpman, and Hoffmaister, 1997). Trade openness can contribute to TFP by allowing an economy greater access to imports of equipment and machinery, in which technological improvements are often embodied, and to a wider range of intermediate inputs, as well as by subjecting domestic firms to more competition (Grossman and Helpman, 1991; Rivera-Batiz and Romer, 1991). More competition can also be associated with a larger share of the private sector in economic activity.

Table 5 summarizes the factors that may have been important for explaining TFP growth in South Africa. In particular, the share of trade in GDP has increased markedly since the opening up of the economy in $1994 .^{26}$ The share of private investment in total investment also increased substantially, as did the share of equipment and machinery. ${ }^{27}$ Augmented Dickey Fuller tests show that private investment in machinery and equipment as a share of total investment (PI), openness (OPEN), and the level of TFP are integrated of order 1. The variables can thus be included in a cointegration analysis to test for a long-run relationship among them. Results from cointegration tests using the Johansen (1988) and Johansen and Juselius (1990) procedures show that a cointegrating relationship exists among the variables,

assumption, it is still true that the turnaround in GDP growth in the recent period owed to TFP growth, whose annual contribution increased from 0.2 percentage points in $1980-93$ to 3.4 percentage points in 1994-2001.

${ }^{25}$ In the empirical exercise below, no robust link was found between TFP growth and R\&D.

${ }^{26}$ Jonsson and Subramanian (2001) show that trade liberalization and openness had a statistically significant positive impact on TFP growth during the 1990s.

${ }^{27}$ Mitra (1994) argues that public investment in transport, communications, and electricity generation led to significant "over-investment" in the sense of excess capacity which could usefully have been employed in other sectors with higher returns. 
and a trace test shows that there is a unique cointegrating vector (Table 6) ${ }^{28}$ The coefficients have the correct sign and are statistically significant: both PI and OPEN are positively correlated with TFP. The cointegration relationship is reported below (with t-statistics in parentheses):

$$
\mathrm{TFP}=-5.25+\underset{[26.1]}{0.74 \mathrm{OPEN}}+\underset{[41.0]}{0.80 \mathrm{PI}}
$$

\section{Short-Run Dynamics of Total Factor Productivity}

The error-correction representation of the cointegrating system can be used to analyze the short-run dynamics of TFP. Exogeneity tests suggest that the OPEN and PI variables are weakly exogenous (Table 7), which indicates that in South Africa openness and private sector participation have influenced TFP but not vice versa. ${ }^{29}$ It is thus appropriate to model the short-run dynamics of TFP as a single equation estimated by ordinary least squares (Table 8).

Starting with a general specification for the short-run error-correction equation for TFP, and deleting variables that are not statistically significant, a parsimonious specification can be derived which satisfies standard diagnostics (Table 8). ${ }^{30}$ In the short run, both trade openness and the private sector share in investment have a positive impact on TFP. To account for the potential short-run impact of the business cycle on TFP growth, capacity utilization was included as an explanatory variable, but it was not statistically significant. A step dummy (DUM), taking a value of 1 during 1994-2001 and 0 before 1994, turned out to be statistically significant. Overall, these results support the conclusion that greater trade openness, private sector participation in the economy, and other policy and institutional changes since 1994 have played a significant role in raising TFP growth in South Africa in recent years.

${ }^{28}$ All variables are expressed in logarithms. The estimation is based on annual data for the period 1980-2001. A lag length of three was chosen using the Schwartz criterion, while taking note that degrees of freedom were severely restricted.

${ }^{29}$ The lagged error term is not significant in the DOPEN and DPI error correction equations, indicating the absence of an error-correction process for these variables.

${ }^{30}$ Statistical tests for a structural break in the relationship between DTFP and the explanatory variables were not definitive. The step dummy was statistically significant, as noted. When the step dummy was omitted from the regression, the hypothesis of a structural break was supported by a likelihood ratio test but not by an F-test. 


\section{Conclusions}

An analysis of potential output in South Africa is useful for policy purposes in terms of strengthening the basis on which to gauge the intensity of resource utilization and impending inflationary pressures. This paper contributes to the literature on the South African economy by providing estimates of the output gap based on three alternative methodologies. The estimates suggest that the annual potential output growth rate during the period since the end of apartheid has been in the $2 \frac{1 / 4}{-3}$ percent range. The output gaps implied by the potential growth estimates are significant in explaining inflation, which underscores their usefulness in the formulation of macroeconomic policy.

Since these estimates are based on historical data, they build in the labor-market and other rigidities that have existed in the past. In future research, it would be useful to extend the analysis of potential output growth to examine the determinants of long-run growth-that is, the question of how the potential growth rate might change over time. An initial step in this direction was taken by Arora, Bhundia, and Bagattini (2003), but it would be useful to combine the analysis of TFP growth in the present paper with an analysis of the determinants of capital formation and employment to provide a richer analysis of longer-run growth possibilities in South Africa. 
Figure 1. Actual GDP and Smoothed Series (In millions of rand)

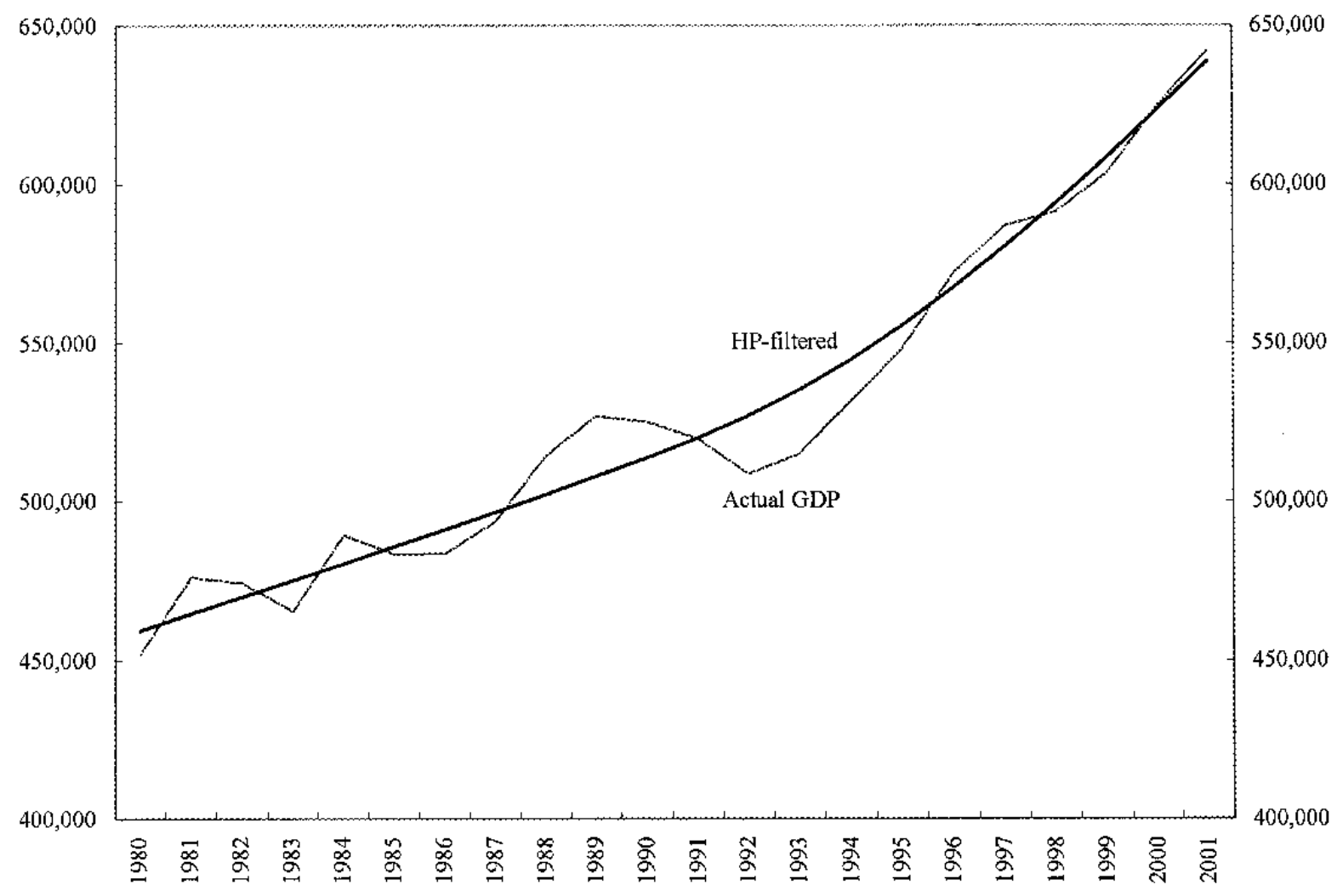


Table 1. Estimates of Potential Output Growth (in percent)

\begin{tabular}{lcc}
\hline Method/source & \multicolumn{2}{c}{ Average for the period } \\
$1980-93$ & $1994-2001$ \\
\hline Hodrick-Prescott filter & 1.2 & 2.2 \\
Structural VAR & 1.1 & 2.8 \\
Production function & 1.3 & 3.0 \\
\hline
\end{tabular}

Source: Authors' estimates.

Table 2. Output Gap in 2001 and Correlations with Capacity Utilization

\begin{tabular}{|c|c|c|}
\hline Output gap methodology & $\begin{array}{l}\text { Output gap in } 2001 \\
(\% \text { of potential GDP) }\end{array}$ & Correlation with Capacity utilization \\
\hline Production function & -0.4 & 0.87 \\
\hline SVAR & -0.3 & 0.21 \\
\hline HP filter & 0.5 & 0.74 \\
\hline
\end{tabular}

Table 3. Phillips Curve Estimates Using the Output Gap Measures

\begin{tabular}{|c|c|c|c|}
\hline & HP Filter & SVAR Method & Production Function \\
\hline \multicolumn{4}{|l|}{ Model 1} \\
\hline Lag length & 2 & 3 & 2 \\
\hline F statistic & $2.19(0.12)$ & $7.16(0.00)$ & $2.42(0.10)$ \\
\hline $\begin{array}{l}\text { Sum (sign) of gap } \\
\text { coefficients }\end{array}$ & $0.26(-+-)$ & $0.42(++-+)$ & $-0.03(-+-)$ \\
\hline $\mathrm{R}^{2} /$ Adjusted $\mathrm{R}^{2}$ & $0.29 / 0.16$ & $0.67 / 0.58$ & $0.33 / 0.19$ \\
\hline No of observations & 19 & 19 & 19 \\
\hline Breusch-Godfrey & $1.31(0.30)$ & $1.65(0.23)$ & $0.23(0.80)$ \\
\hline \multicolumn{4}{|l|}{ Model 2} \\
\hline Lag length & 1 & 2 & 1 \\
\hline F statistic & $3.18(0.06)$ & $8.80(0.00)$ & $3.86(0.04)$ \\
\hline $\begin{array}{l}\text { Sum (sign) of gap } \\
\text { coefficients }\end{array}$ & $0.23(-+)$ & $0.17(++-)$ & $0.18(-+)$ \\
\hline $\mathrm{R}^{2} /$ Adjusted $\mathrm{R}^{2}$ & $0.27 / 0.19$ & $0.64 / 0.57$ & $0.33 / 0.24$ \\
\hline No. of observations & 19 & 19 & 19 \\
\hline Breusch-Godfrey & $1.25(0.31)$ & $0.20(0.82)$ & $0.26(0.78)$ \\
\hline
\end{tabular}


Table 4. Contributions to Growth, 1980-2001

\begin{tabular}{lrrr}
\hline & $1980-93$ & $1994-2001$ & $1980-2001$ \\
\hline Real GDP growth (in percent) & 1.0 & 2.8 & 1.7 \\
Contributions (in percentage points) & & & \\
Capital & 0.9 & 0.6 & 0.8 \\
Labor & 0.1 & -0.9 & -0.3 \\
TFP & 0.0 & 3.1 & 1.2 \\
\hline
\end{tabular}

Sources: Statistics South Africa; and authors' estimates.

Table 5. Selected Factors Affecting TFP Growth, 1980-2001 (in percent)

\begin{tabular}{|c|c|c|}
\hline & $1980-93$ & 1994-2001 \\
\hline Share of trade in real GDP & 34.2 & 46.6 \\
\hline Share of equipment and machinery in investment & 35.4 & 50.4 \\
\hline Share of private business sector in investment & 60.1 & 72.1 \\
\hline $\begin{array}{l}\text { Share of private business sector in investment in } \\
\text { equipment and machinery }\end{array}$ & 61.8 & 73.1 \\
\hline
\end{tabular}

Sources: South African Reserve Bank; and authors' estimates. 
Figure 2. Actual Output, Potential Output, and Output Gap, 1980-2001

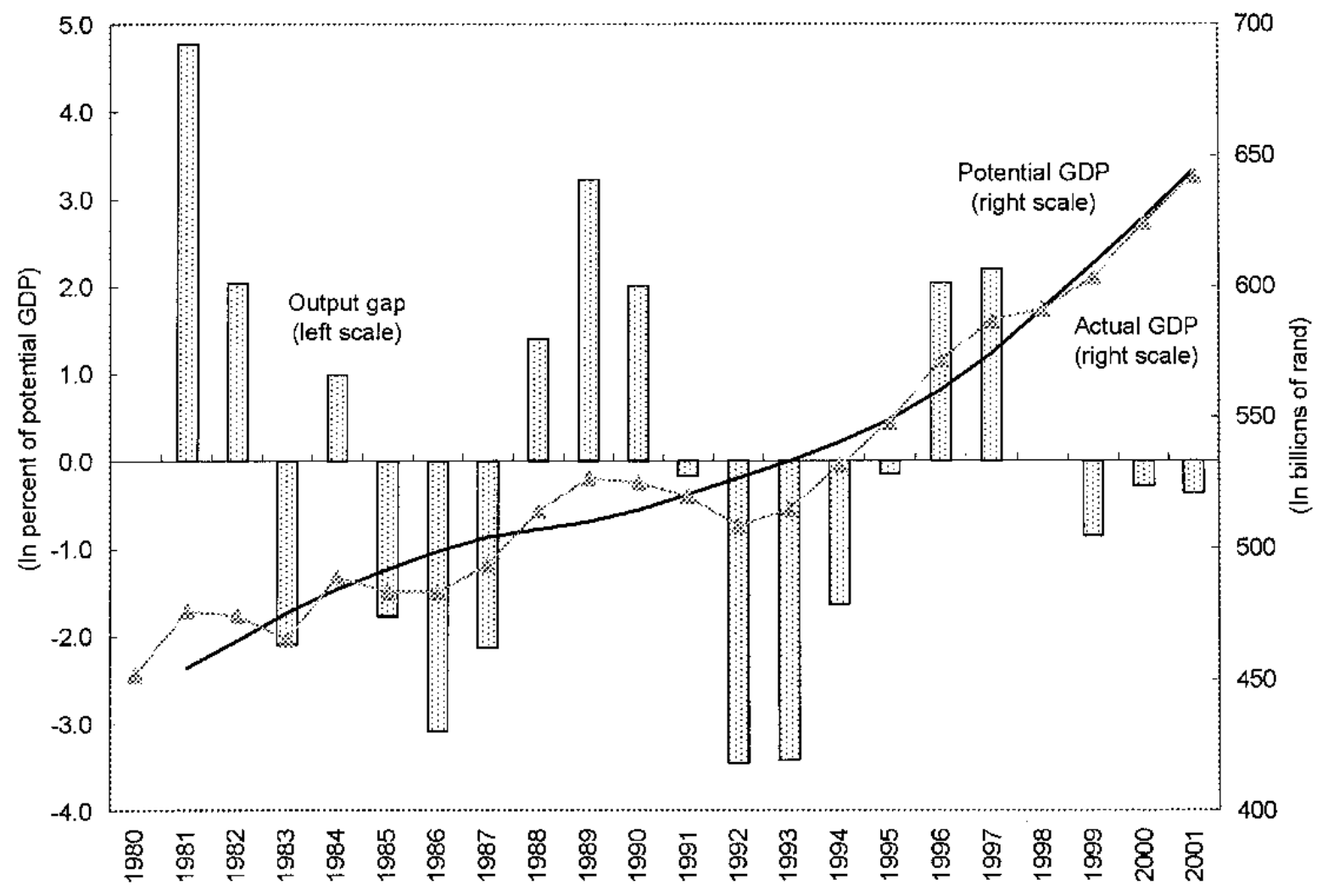


Figure 3. Output Gap, Inflation, and Capacity Utilization, 1980-2001

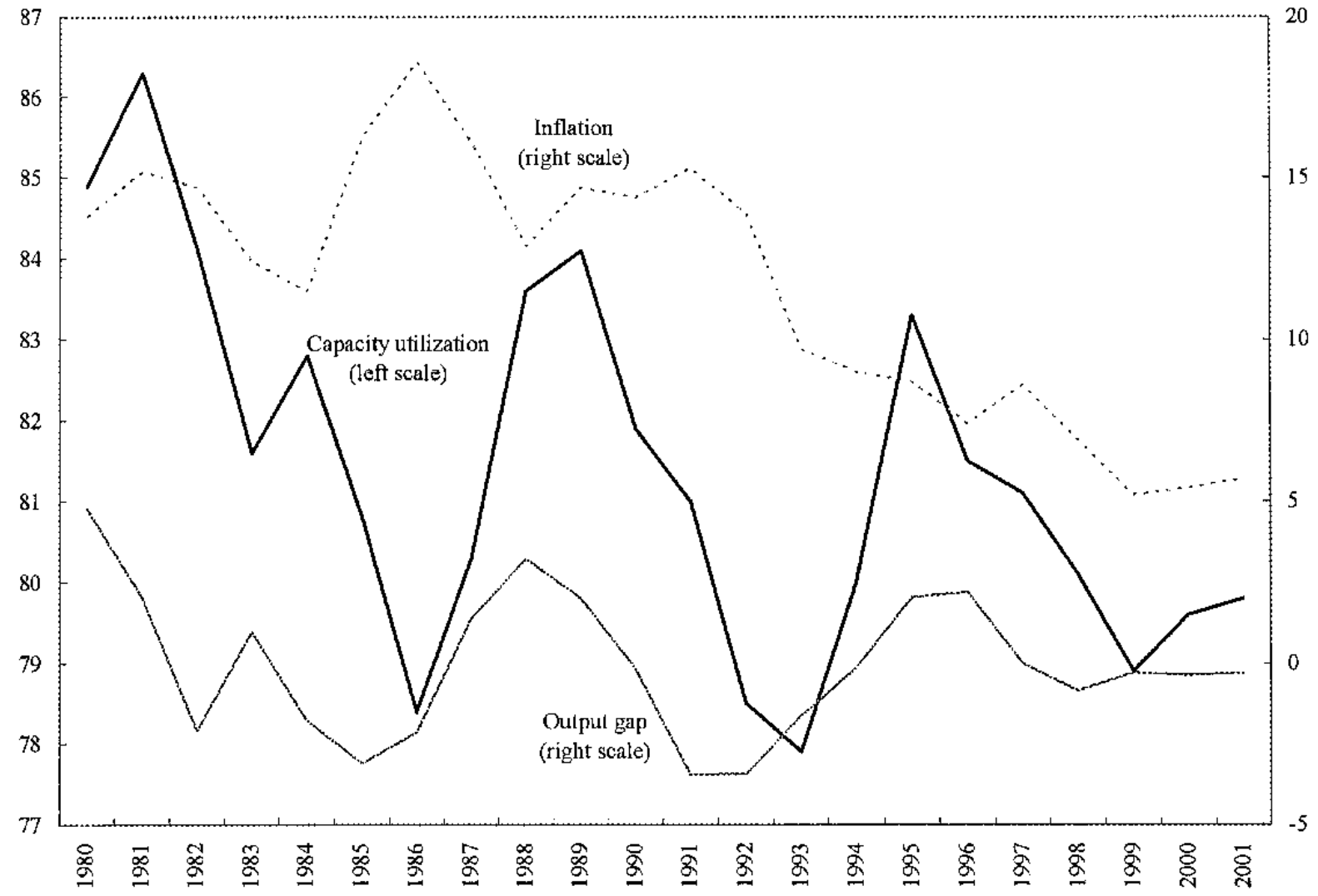


Table 6. The Johansen Cointegrating Test for TFP, OPEN and PI

\begin{tabular}{llllll} 
Number of CVs & Eigenvalue & Trace statistic & $5 \%$ critical value & $1 \%$ critical value \\
\hline None** & 0.94 & 61.11 & 29.68 & 35.65 \\
At most 1 & 0.42 & 9.81 & 15.41 & 20.04 \\
At most 2 & 0.00 & 0.01 & 3.76 & 6.65 \\
\hline
\end{tabular}

** indicates rejection of the hypothesis at the $1 \%$ level

Table 7. The Error-Correction Process and Test of Weak Exogeneity

\begin{tabular}{ll}
\hline Error correction equation & $\begin{array}{l}\text { Error correction } \\
\text { Coefficient and t-value }\end{array}$ \\
\hline DTFP & $-1.31(-5.57)^{*}$ \\
DOPEN & $-1.03(-1.56)$ \\
DPI & $0.11(0.19)$ \\
\hline
\end{tabular}

Table 8. Short-run Determinants of Total Factor Productivity

\begin{tabular}{|c|c|c|c|}
\hline & \multicolumn{3}{|c|}{ Dependent variable: DTFP } \\
\hline Constant & $\begin{array}{c}0.01 \\
3.701\end{array}$ & $\begin{array}{c}0.22 \\
{[2.07]}\end{array}$ & $\begin{array}{c}0.01 \\
{[2.53]}\end{array}$ \\
\hline $\operatorname{ECM}(-1)$ & $\begin{array}{l}-0.84 \\
{[-4.59]}\end{array}$ & $\begin{array}{c}-0.93 \\
{[-5.41]}\end{array}$ & $\begin{array}{c}-0.63 \\
{[-3.71]}\end{array}$ \\
\hline DTFP(-1) & $\begin{array}{l}-0.66 \\
{[-2.81]}\end{array}$ & $\begin{array}{c}-0.60 \\
{[-2.83]}\end{array}$ & $\begin{array}{l}-0.66 \\
{[-3.47]}\end{array}$ \\
\hline DOPEN & $\begin{array}{c}0.36 \\
{[2,86]}\end{array}$ & $\begin{array}{c}0.33 \\
{[2.92]}\end{array}$ & $\begin{array}{l}+0.24 \\
{[2.20]}\end{array}$ \\
\hline DPI & $\begin{array}{c}1.06 \\
{[6.20]}\end{array}$ & $\begin{array}{l}1.08 \\
17.01]\end{array}$ & $\begin{array}{c}0.88 \\
{[5.71]}\end{array}$ \\
\hline $\mathrm{CU}$ & & $\begin{array}{l}-0.25 \\
{[-1.95]}\end{array}$ & \\
\hline DUM & & & $\begin{array}{c}0.02 \\
{[2.72]}\end{array}$ \\
\hline LM test statistic & $0.03(0.97)$ & $3.32(0.08)$ & $3.13(0.09)$ \\
\hline Adjusted R-square & 0.80 & 0.78 & 0.87 \\
\hline No. of observations & 17 & 17 & 17 \\
\hline
\end{tabular}

t-statistics are reported in brackets. ECM(-1) is the lagged error-correction term from the cointegrating vector (see above). The LM test statistic was based on four lags, and p-value is indicated in the parentheses. 


\section{Variables}

All variables are from the South African Reserve Bank, unless otherwise stated.

GDP - real gross domestic product measured (1995 prices, seasonally adjusted)

Inflation - percent change in the consumer price index (CPI)

OPEN -Measure of openness. Openness is measured as the ratio of the sum of exports and imports of goods and non-factor services to GDP, International Financial Statistics.

PI - private business investment in machinery and equipment as a share of total investment in South Africa.

Capital stock - total fixed capital stock measured (1995 prices).

Employment - formal employment (millions).

Capacity Utilization - percent utilization of total manufacturing sector capacity. 


\section{References}

Arora, V., A. Bhundia, and G. Bagattini, 2003, "Potential Output and the Sources of Growth," Chapter IV of South Africa-Selected Issues, IMF Staff Country Report No. $03 / 18$.

Blanchard, O., and D. Quah, 1989, "The Dynamic Effects of Aggregate Demand and Supply Disturbances," American Economic Review, 79, pp. 655-73.

Chadha, B., 1995, "Disequilibrium in the Labor Market in South Africa," IMF Staff Papers, Vol. 42 , No. 3, pp. 642-669.

Coe, D., E. Helpman, and A. Hoffmaister, 1997, "North-South R\&D Spillovers," The Economic Journal, Vol. 107 (January), pp. 134-139.

Coe, David and John McDermott, 1997, "Does the Output Gap Work for Asia?", IMF Staff Papers, Vol. 44, No. 1, pp. 59-79.

De Jager, B., and D. Smal, 1984, "Potential Gross Domestic Product of South Africa," South African Reserve Bank, Quarterly Bulletin, No. 154: 21-27, December.

De Masi, P., J. Chan-Lau, and A. Keenan, 1999, "Measures of Potential Output, NAIRU, and Capacity Utilization," in United States-Selected Issues, IMF Staff Country Report No. 99/101.

De Wet, G., 1995, "The Prognosis for Growth and Development in South Africa," South African Journal of Economics, 63: 473-488, December.

Dupasquier, C., A. Guay, and P. St-Amant, 1997, "A Comparison of Alternative Methodologies for Estimating Potential Output and the Output Gap," Bank of Canada Working Paper 97-5.

Grossman, G., and E. Helpman, 1991, Innovation and Growth in the Global Economy (Cambridge, Massachusetts: MIT Press).

Hodrick, R., and E. Prescott, 1997, "Postwar U.S. Business Cycles: An Empirical Investigation," Journal of Money, Credit, and Banking, Vol. 29, pp. 1-16.

International Monetary Fund, 1998, "Growth Accounting," in South Africa-Selected Issues, IMF Staff Country Report No. 98/96, October.

Jonsson, G., and A. Subramanian, 2001, "Dynamic Gains from Trade: Evidence from South Africa," IMF Staff Papers, Vol. 48, No. 1, pp. 197-224 (International Monetary Fund: Washington, DC). 
Lewis, J., 2001, "Policies to Promote Growth and Employment in South Africa," Informal Discussion Paper on Aspects of the Economy of South Africa, No. 16, The World Bank.

Minford, Patrick, 1997, "Growth, Employment, and Economic Reform: Lessons for South Africa," South African Journal of Economics, 65: 433-58, December.

Mitra Raja, 1994, "Public Expenditure Trends in South Africa," unpublished., The World Bank, October.

Rivera-Batiz, L., and P. Romer, 1991, "Economic Integration and Endogenous Growth," The Quarterly Journal of Economics, Vol. CVI (May), pp. 531-55.

Romer, Paul, "The Origins of Endogenous Growth," Journal of Economic Perspectives, Vol. 8., No. 1, pp. 3-22.

Sarel, M., 1997, "Growth and Productivity in ASEAN Countries," IMF Working Paper, WP/97/97.

South African Reserve Bank, 2003, Quarterly Bulletin, March 2003, page S-147.

Strydom, P.D.F., 1995, "International Trade and Economic Growth: The Opening-Up of the South African Economy," South African Journal of Economics, 63: 556-76, December.

United Nations, 2002, World Urbanization Prospects: The 2001 Revision (New York: The United Nations).

U.S. Congressional Budget Office, 2001, "CBO's Method for Estimating Potential Output: An Update," (Washington, DC: CBO). 